\title{
The Gametophyte and Embryo of Botrychium obliquum, Mühl.
}

\author{
BY \\ DOUGLAS HOUGHTON CAMPBELL, \\ Stanford University, California.
}

With Plate VIII and eleven Figures in the Text.

$\mathrm{T}^{\mathrm{H}}$ HE genus Botrychium comprises about thirty-five species, ${ }^{1}$ of which about half occur in the United States. Most of the species are found in temperate regions, the few that occur within the tropics inhabiting the cooler mountain districts.

Our knowledge of the gametophyte and embryo is based mainly upon a study of two species, B. Lunaria, (L.) Sw., ${ }^{2}$ and B. virginianum, (L.) Sw. ${ }^{3}$ In 1905 Lyon ${ }^{4}$ published a brief account of the embryo of $B$. obliqumm, Mühl., which was found to differ so much from the other species that he proposed to separate it as the type of a new genus, Sceptridium.

Dr. Lyon has very generously turned over to the writer his collection of gametophytes of $B$. obliquum, and also a large series of sections which he had made, as well as a number of photographs. From Dr. Lyon's sections, supplemented by sections made by the writer, a fairly complete study was macie of the development of the reproductive organs and embryo, and it was thus possible to examine in detail the differences between B. obliquum and the two other species whose development was known.

\section{The Gametophyte.}

The structure of the gametophyte of $B$. obliqumm is much like that of the other species that have been investigated. The gametophyte is a subterranean, tuberous body, somewhat flattened horizontally and having a median, longitudinal, dorsal ridge upon which the antheridia are produced. The mature gametophyte (Pl. VIII, Figs. 3,4; Text-fig. 1 ) is about 3 to $6 \mathrm{~mm}$.

1 Christensen, C. : Index Filicum, I906.

${ }^{2}$ Hofmeister: The Higher Cryptogamia. Ray Society, 1862. Bruchmann, H. : Flora, xevi. 203,1906 .

3 Jeffrey, E. C. : Proc. Canad. Instit., 1898 . Campbell, D. H. : The Eusporangiatae. Carnegie Institution Publication, No. I40, I9I I.

${ }^{4}$ Lyon, H. L. : Bot. Gaz., xl. $455,1905$.

[Annals of Botany, Vol. XXXV. No. CXXXVIII. April, 192x.] 
length and about half as wide. In size it is intermediate between $B$. Lunaria and $B$. virginianum.

The youngest specimens available (Pl. VIII, Figs. I, 2) were broadly oval in outline, $\frac{3}{4}$ to $I \frac{1}{2} \mathrm{~mm}$. in length, and the antheridial ridge had not yet developed. These young specimens had numerous long rhizoids, which are much less conspicuous in the more advanced stages.

As the gametophyte develops, it becomes relatively narrower, and often less regular in outline, and a more or less conspicuous median ridge is formed, upon which are borne the antheridia (Fig. 3). These begin to

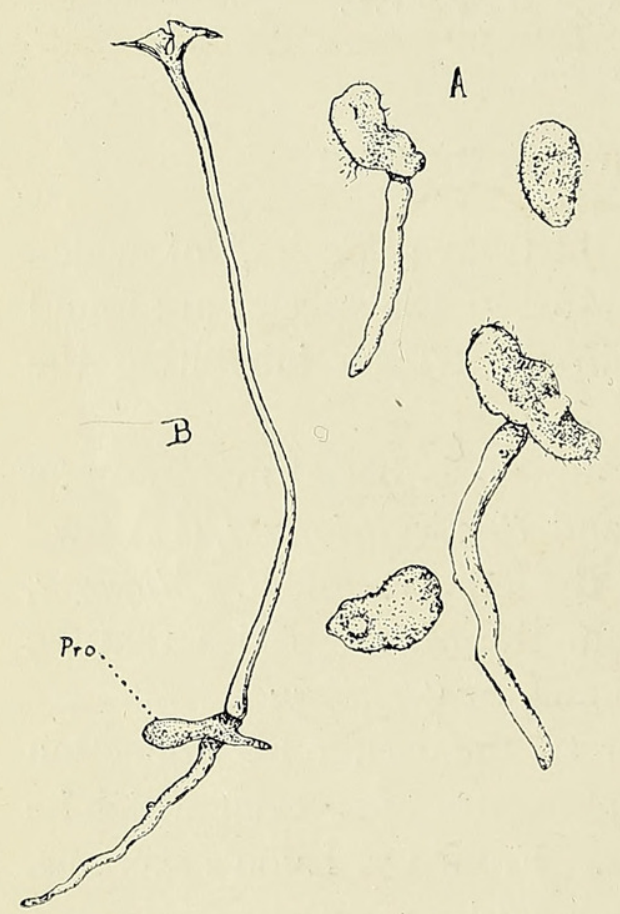

TeXT-FIG. I. A. Gametophytes of Botrychium obliquum, Muihl., some with attached sporophytes. $\times$ about 3 . B. Young sporophyte with expanded cotyedon, attached to the gametophyte. Pro. natural size. From photograph by Dr. H. L. Lyon.

intact, as has been noted in other cases (Fig. IO).

The endophyte of $B$.obliquum closely resembles that of $B$. virginianum, and, as in that species, there may be developed thick-walled spores (?) ${ }^{1}$ (Fig. IO, sp.).

Jeffrey $^{2}$ thinks that the endophyte is related to the genera Pythium and Completoria, but has not proposed a name for it.

No further study of the endophyte was made, as it does not seem to differ materially from that of $B$. virginianum.

\footnotetext{
1 Campbell: loc. cit.
}

2 Jeffrey : loc. cit. 


\section{The Antheridium.}

The gametophyte is monoecious, but there is a good deal of difference in the relative number of antheridia and archegonia in different individuals.

The antheridia usually are produced in considerable numbers upon the median ridge, and, as usual, begin to develop before the archegonia. The latter as a rule form a row on either side of the antheridial ridge, but are not developed upon the ridge itself (Figs. I I, I2).

The development of the antheridium is very much like that of the other species (Figs. I3-I 5). The mother-cell divides first by a transverse wall into an outer, or primary, cover cell, and an inner cell from which the sperm cells finally develop.

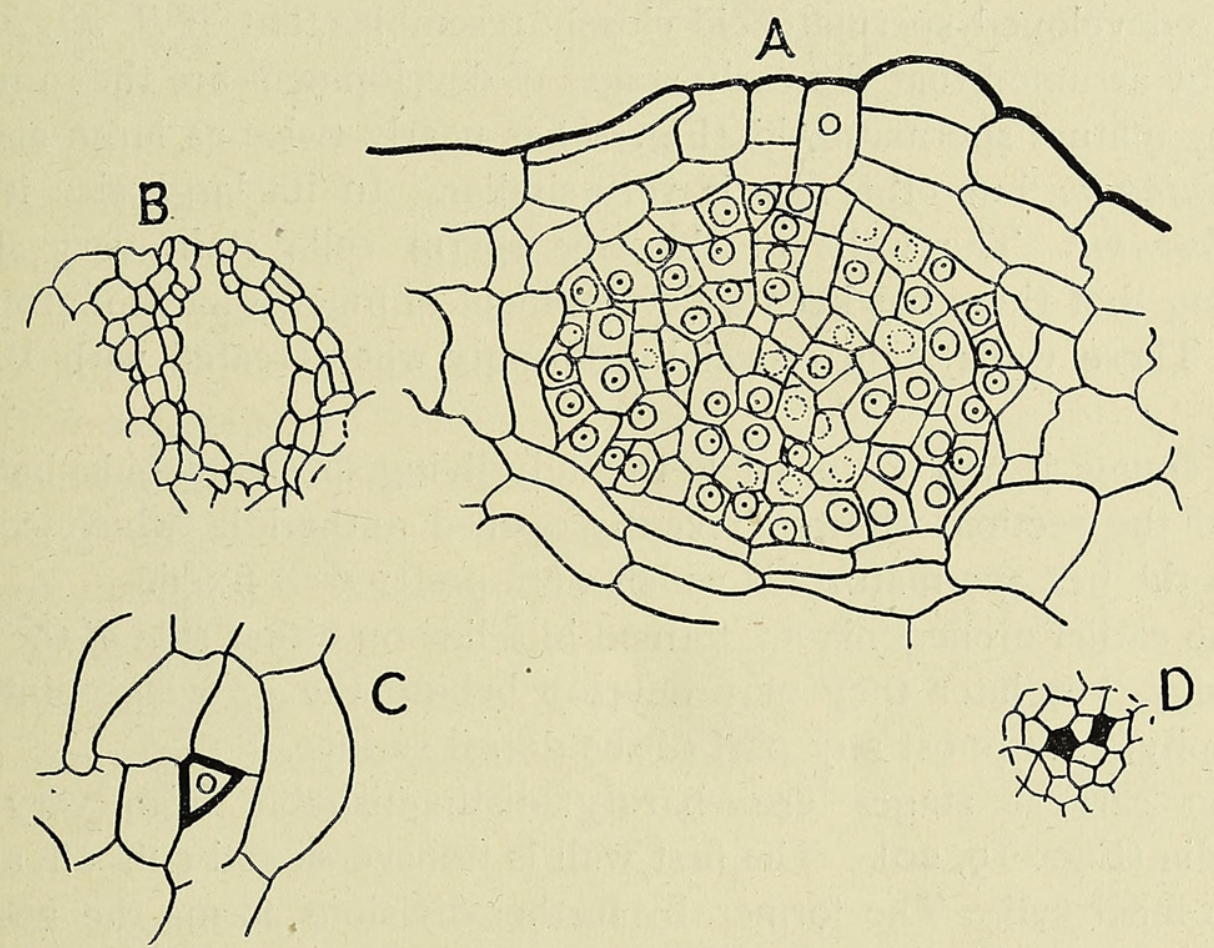

TEXT-FIG. 2. A. Median section of an antheridium just before the final division of the spermatocytes. $\times 270$. 0 , opercular cell. B. Empty antheridium. $\times 90$. C. Surface view of antheridium with triangular opercular cell. $\times 2$ \%. D. Surface view of antheridium with two opercular cells. $\times 90$.

The primary cover cell divides by vertical. walls into several cells, in which horizontal walls are formed, so that there are two layers of cover cells. The horizontal wall is suppressed in one of the cover cells, however, and this becomes the opercular cell, where the antheridium opens. A second opercular cell is sometimes present (Text-fig. 2, D), but as a rule only one is formed. This opercular cell is destroyed at the time of dehiscence. In cross-section the opercular cell is generally four-sided, but sometimes it is triangular, as in Ophioglossum (Text-fig. 2, C).

The first division in the inner cell of the young antheridium may be either transverse or vertical, and is next followed by a wall at right 
angles to the first one. The later divisions do not show any definite order, and the number of spermatocytes formed varies a good deal.

The material was not particularly favourable for a study of spermatogenesis, and, as there was nothing to indicate any deviation from what has been observed in other Ophioglossaceae, no attempt was made to study it in detail.

It may be assumed that, as in other pteridophytes, the body of the spermatozoid is derived mainly from the nucleus of the spermatocyte. The nucleus becomes an almost homogeneous, thickened band tapering towards the anterior end of the spermatozoid. In the later stages, the slender coiled blepharoblast, from which the numerous cilia arise, can be readily demonstrated, but the earlier stages of the blepharoblast were not studied. As the fully developed spermatozoid closely resembles that of $B$. virginianum, it may be assumed that the early stages of development are the same.

The mature spermatozoid (Fig. I8) is nearly twice as large as that of B. virginianum, but otherwise is very similar. In its large size it recalls Ophioglossum. ${ }^{1}$ The walls of the ripe sperm cells stain very strongly, indicating that there has been a development of mucilaginous matter in the walls. These walls stain especially strongly when treated with Bismarck brown.

Of course it was not possible to study living spermatozoids, but a good many of the sections showed recently opened antheridia which contained some of the free spermatozoids which were pretty well fixed.

The earlier archegonia are formed in a line on either side of the antheridial ridge, but later they may develop behind the growing-point of the gametophyte at almost any part of the dorsal surface.

The earliest stages are hardly distinguishable from very young antheridia (Figs. I9, 20). The first wall is transverse and cuts off an outer from an inner cell. The former, by further divisions, forms the neck cells, the latter the egg and canal cells. As a rule no basal cell is present, but sometimes it looks as if such a cell might occasionally be formed.

The cover cell is usually rather shallow, but sometimes may equal in depth the inner cell (Text-fig. 3, A). As in all ferns, the first divisions in the cover cell are intersecting median vertical walls determining the four rows of neck cells.

By the time the first divisions in the cover cell are completed, the inner cell begins to grow up between the four neck cells, and as these elongate and undergo further divisions, there is formed a slender extension of the central cell which later is cut off from it as the neck canal cell. The separation of the canal cell from the central cell occurs at an unusually late period in $B$. obliqum when compared with the other Ophioglossaceae.

Each of the four primary neck cells divides by a series of oblique 
transverse walls into about six. Of these the upper half, approximately, extend above the surface of the gametophyte, the others lying below it (Text-fig. 3).

The nucleus of the neck canal cell later divides into two, but no cases were seen where a division wall had been formed, as is not unusual in Ophioglossum pendulum, but has not yet been demonstrated in Botrychium.

The presence of a ventral canal cell could not be demonstrated satis-
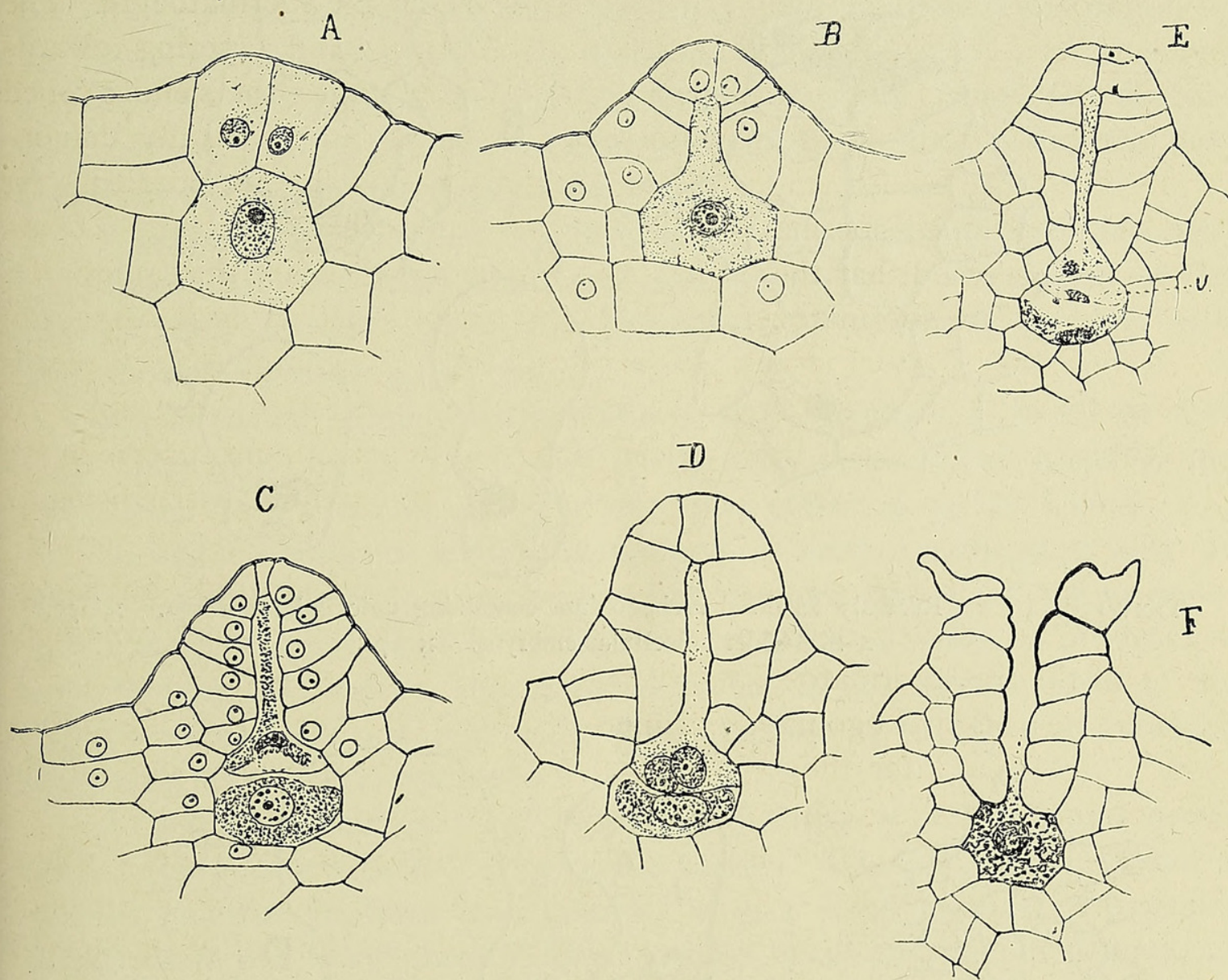

TEXT-FIG. 3. A. Young archegonium. $\times 320$. B-D. Older archegonia. $\times 2$ o. E. Mature archegonium, showing apparent ventral canal cell, $v . \times 240$. F. Open, but unfertilized, archegonium. $\times 240$.

factorily, although several preparations were secured which indicated that a ventral canal cell-or at least a nucleus representing this-was present. In Fig. 22 there is shown one such case, where in close contact with the nucleus of the central cell a second smaller nucleus is visible and a zone of somewhat denser cytoplasm, but no evident cell wall. In Text-fig. 3, E, another example is shown. In this instance there was apparently a small cell between the egg and the neck canal cell. The nucleus of this cell (?) was small and not very distinct.

A similar difficulty in demonstrating a ventral canal cell has been experienced by the writer in his investigations of other Ophioglossaceae. It seems probable that in all of these the ventral canal cell is cut off very 
soon before the opening of the archegonium and almost immediately ejected. It is also not unlikely that there may be no division wall formed and that the ventral canal cell is represented merely by a nucleus.

When the archegonium opens the terminal neck cells diverges widely, presenting a decidedly characteristic appearance (Text-fig. $3, \mathrm{~F}$ ).
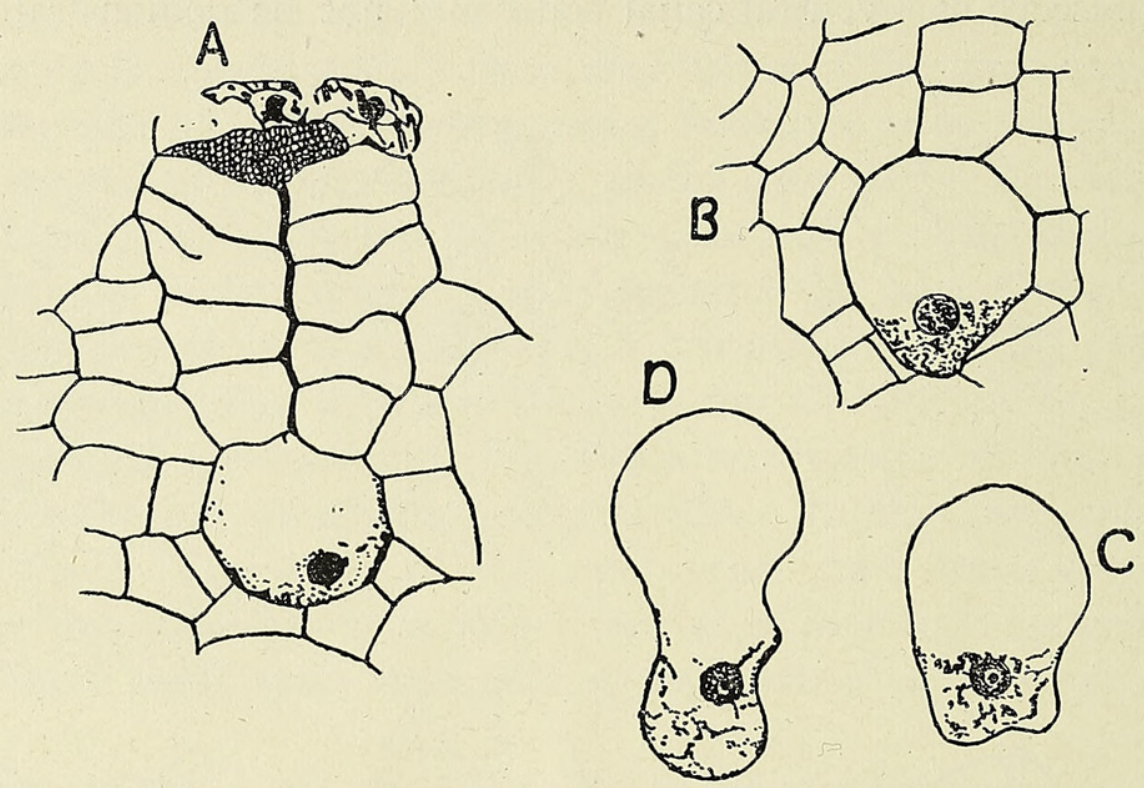

TEXT-FIG. 4 A. Recently fertilized archegonium containing unicellular embryo. $\times 270$. B-D. Older unicellular embryos. $\times 2$ \%

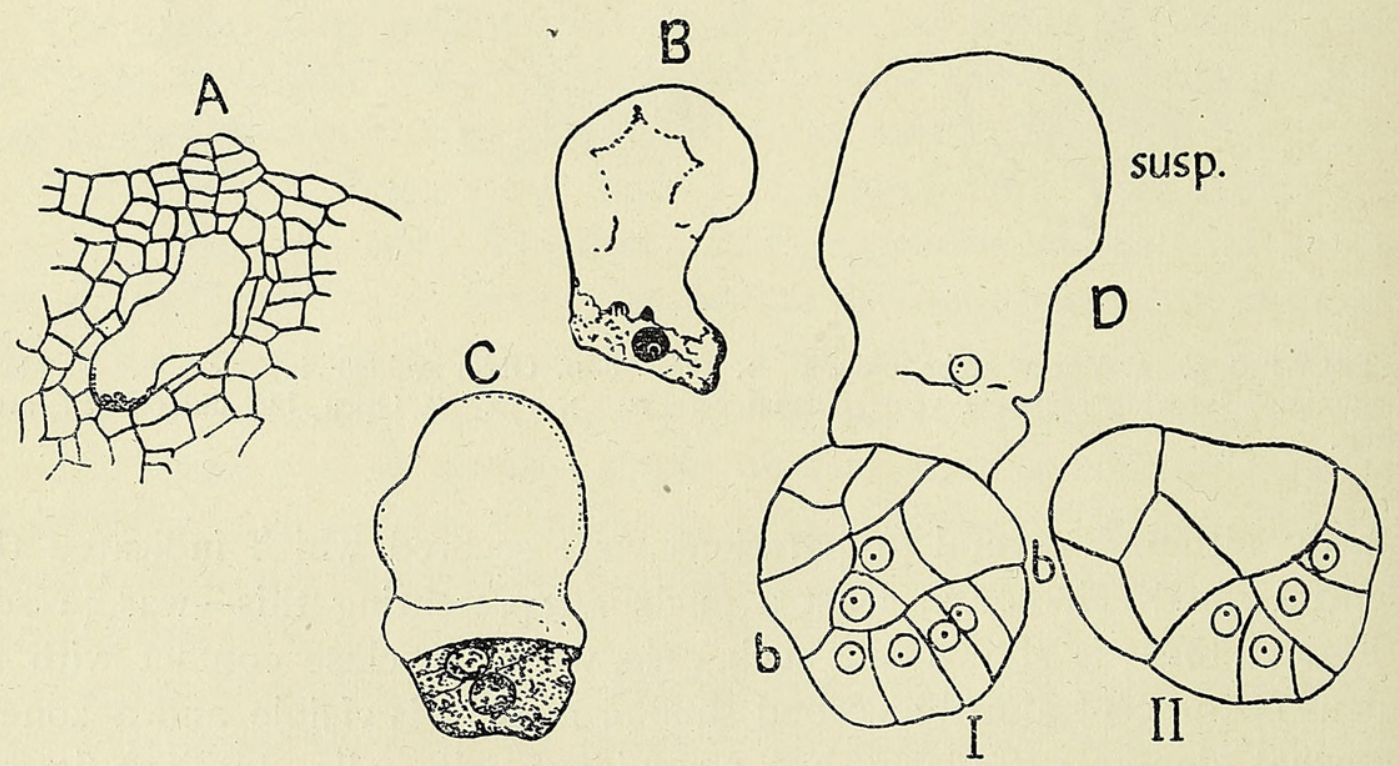

TeXT-FIg. 5. A. Archegonium containing much elongated unicellular embryo. $\times$ roo. B. First division in the embryo. $\times 270$. C. An older stage. $\times 270$. D. Two sections of an older embryo. $\times 270$. I shows the large suspensor, susp.; $b-b$, basal wall.

In both $B$. Lunaria and B. virginianum a somewhat larger part of the neck is free than in $B$. obliqumm. In this respect the latter shows a certain resemblance to Ophioglossum and the Marattiaceae. 


\section{THE EMBRYo.}

The embryo of $B$. obliqum differs remarkably from that of either $B$. Lunaria or B. virginianum. Lyon ${ }^{1}$ called attention to the presence of a conspicuous suspensor and a very different orientation of the cotyledon and root when compared with B. virginianum. He describes and figures the young sporophyte at about the time that the root emerges from the gametophyte, but he does not state just what is the relation of the organs of the young sporophyte to the early divisions of the embryo.

Bower $^{2}$ has figured several unicellular embryos from Dr. Lyon's preparations, showing the marked elongation of the embryo before the first cell division, but no later stages were found.

B. obliquum was the first fern in which a suspensor was demonstrated, but subsequently the writer discovered a suspensor in two members of the Marattiaceae, Danaea ${ }^{3}$ and Macroglossum. ${ }^{4}$ Helminthostachys has also been shown to possess a suspensor. ${ }^{5}$

The following account of the embryo of B. obliquum is based in part upon slides made by Dr. Lyon, and partly upon preparations made by the writer from prothallia and young sporophytes collected by Dr. Lyon.

Unicellular embryos are not uncommon, as several archegonia may be fertilized, and begin to form embryos; but the later stages are not so easily found, and it was not possible to secure as complete a series as might have been wished. However, the essential points in the development of the embryo were made out, and there is no question as to the way in which the young sporophyte develops.

As usual, the fertilized egg immediately forms a cell-wall, and grows until it completely fills the cavity of the venter. The unicellular embryo is at first globular in form, and contains only a small amount of granular cytoplasm in which is embedded the relatively small nucleus (Text-fig. 4, A). The lower part of the embryo next becomes slightly pointed, and this projection contains most of the granular contents of the cell, and the nucleus, which has become somewhat larger. The embryo now grows downward, as Bower has shown, and bores its way into the adjacent prothallial tissue. Sometimes it grows vertically downward, but more often its course is more or less oblique. At this stage it forms a somewhat irregular tube, whose apex is narrower than the basal portion within the venter of the archegonium. The nucleus and the surrounding granular cytoplasm, which has increased considerably in amount and shows a more or less evident areolation, occupy the growing apex of the embryo-tube, which may be three times as long as wide before the first cell division occurs (Text-fig. $5, \mathrm{~A}$ ).

1 Loc. cit.

2 Bower, F. O. : Origin of a Land Flora, Fig. 266.

3 Campbell : loc. cit.

${ }^{4}$ Campbell : Ann. Bot., xxviii. 652, I914. ${ }_{5}$ Lang, W. H. : Ann. Bot., xxiv. 61 I, 1910. 
Only a small number of the next stages were found, and these were not very well fixed and showed more or less shrinkage. Text-fig. 5, B, shows the first division in the embryo, by which the large suspensor cell is cut off from the terminal cell which is to form the embryo proper. This division is transverse, and is followed by a second division in the terminal cell which probably is to be considered as the basal wall, dividing the embryo into an epibasal and a hypobasal region. So far as could be judged, the direction of the basal wall is always approximately horizontal. There is probably some variation in the orientation of the basal wall with reference to the
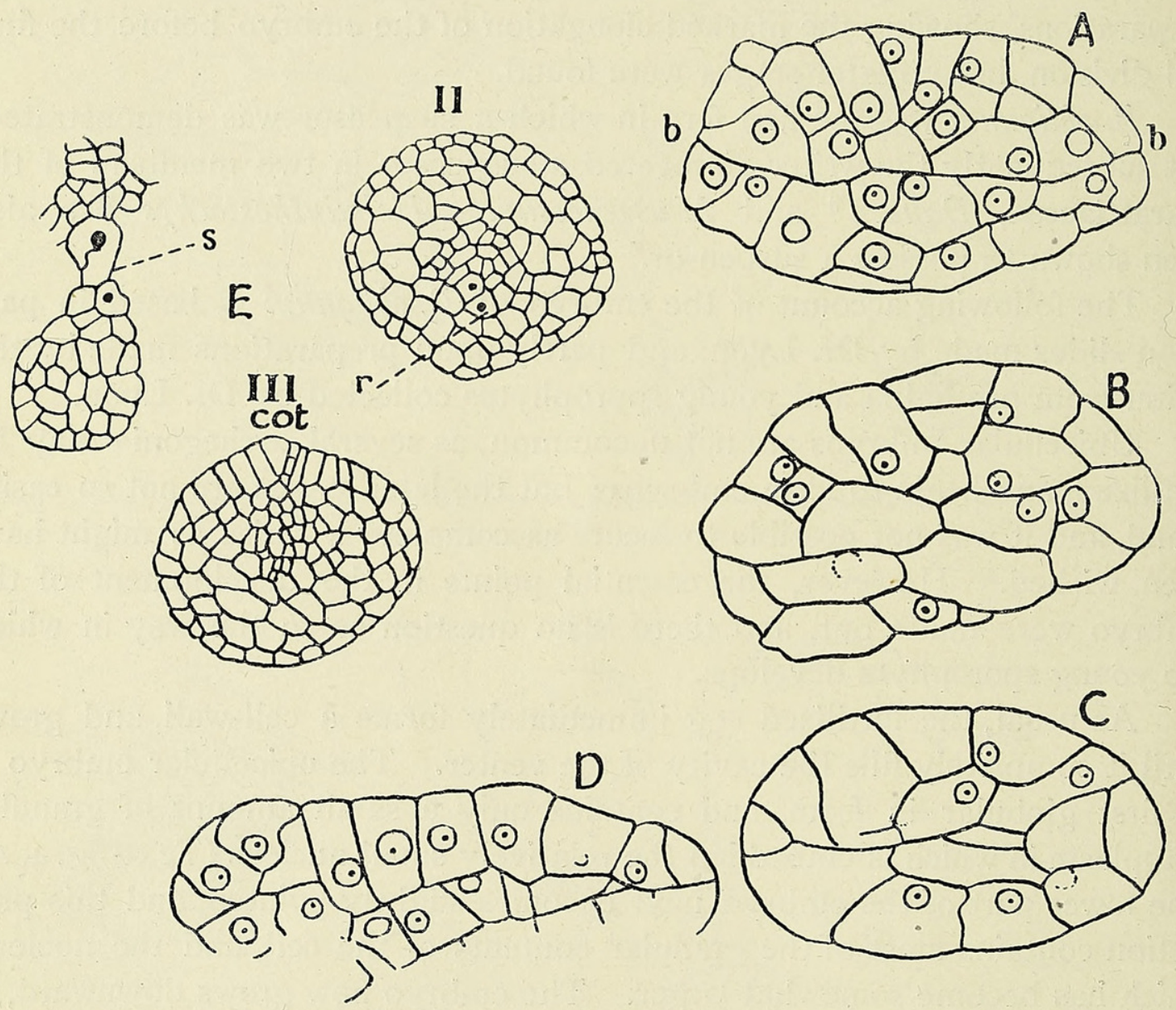

TEXT-Fig. 6. A-n. Four of a series of sections of a young embryo. $\times 270 . \quad b-b$, the basal wall. E. Three similar sections of an older embryo in which the cotyledon and root are already evident. $\quad s$., suspensor; $r$, root initial ; cot., cotyledon. $\times$ i०o.

axis of the suspensor cell, which also is sometimes almost horizontal in position.

Text-fig. 5, D, shows two sections of a somewhat older embryo. The nearly globular embryo is attached to the large suspensor cell, and is probably cut in a nearly median plane. The epibasal region is occupied by a series of columnar cells, the central one of which is possibly the initial for the stem apex. Just below the basal wall is a triangular cell which suggests a root initial; but as no stages between this embryo and much 
more advanced ones were found, the true nature of these apical (?) cells must for the present remain in doubt.

The next stages, which were a good deal more advanced, were remarkably like corresponding ones in the Marattiaceae, especially Danaea.

Text-fig. 6, A-D, shows four of a series cut vertically, showing plainly the basal wall $(b-b)$. The embryo was broadly oval in outline, the major axis being transverse, as it is in corresponding stages of various Marattiaceae. Occupying the central portion of the epibasal region, there is a group of superficial columnar cells, which may mark the beginning of the cotyledon, but this is not at all certain. In this embryo there was nothing which could be interpreted as a root, and the whole of the hypobasal portion formed the large foot.

The next stage found (Text-fig. 6, E) was considerably older, and also strongly resembled the embryo of Danaea. The vertical axis of the embryo was now equal to the transverse, and the upper part was slightly pointed with what looked like a single apical cell marking the position of the cotyledon. The primary vascular bundle, which later extends through the cotyledon and root, is indicated by a group of actively dividing cells below the cotyledon apex.

The primary root in B. obliquum closely resembles in its origin that of Ophioglossum and the Marattiaceae. A single initial cell arises near the centre of the embryo, very near the basal wall (Text-fig. 6, E). In the embryo figured, the first segment has been cut off from the initial cell. It is difficult to say whether the root belongs to the epibasal or hypobasal region, as it is so near the centre of the embryo.

Text-fig. 7, A, shows two longitudinal sections of a more advanced stage in which the apical cell of the root is very conspicuous and the primary vascular bundle extends from the cotyledon into the root. The section passes through the apex of the cotyledon, which shows a very evident apical cell. The apical cell of the root is extremely conspicuous and closely resembles that of the roots of other Ophioglossaceae.

As in Ophioglossum moluccamum and the Marattiaceae, there is no question that the vascular system in B. obliquum begins as a single strand common to cotyledon and root and having no connexion with the stem apex. The latter (Text-fig. 7, A, II) at this stage consists of a small group of superficial cells, lying somewhat to one side of the centre of the flattened area forming the top of the embryo, which is somewhat topshaped in outline, closely resembling similar stages in Danaea. ${ }^{1}$ There is a single apical cell, which is somewhat larger than the neighbouring cells. In longitudinal section this cell is oblong in outline, with a broad, truncate base. In older stages, the lateral walls of the apical cell usually converge towards the top, which is thus narrower than the base.

1 Campbell : Eusporangiatae, Figs. I I 7 -I 9. 
This type of apical cell is found in most species of Ophioglossum, and in many Marattiaceae, but is unlike that of either $B$. virginianum or B. Lunaria.

Very soon after the cotyledon and stem apex are recognizable, the second leaf arises as a group of meristem cells close to the stem apex. The
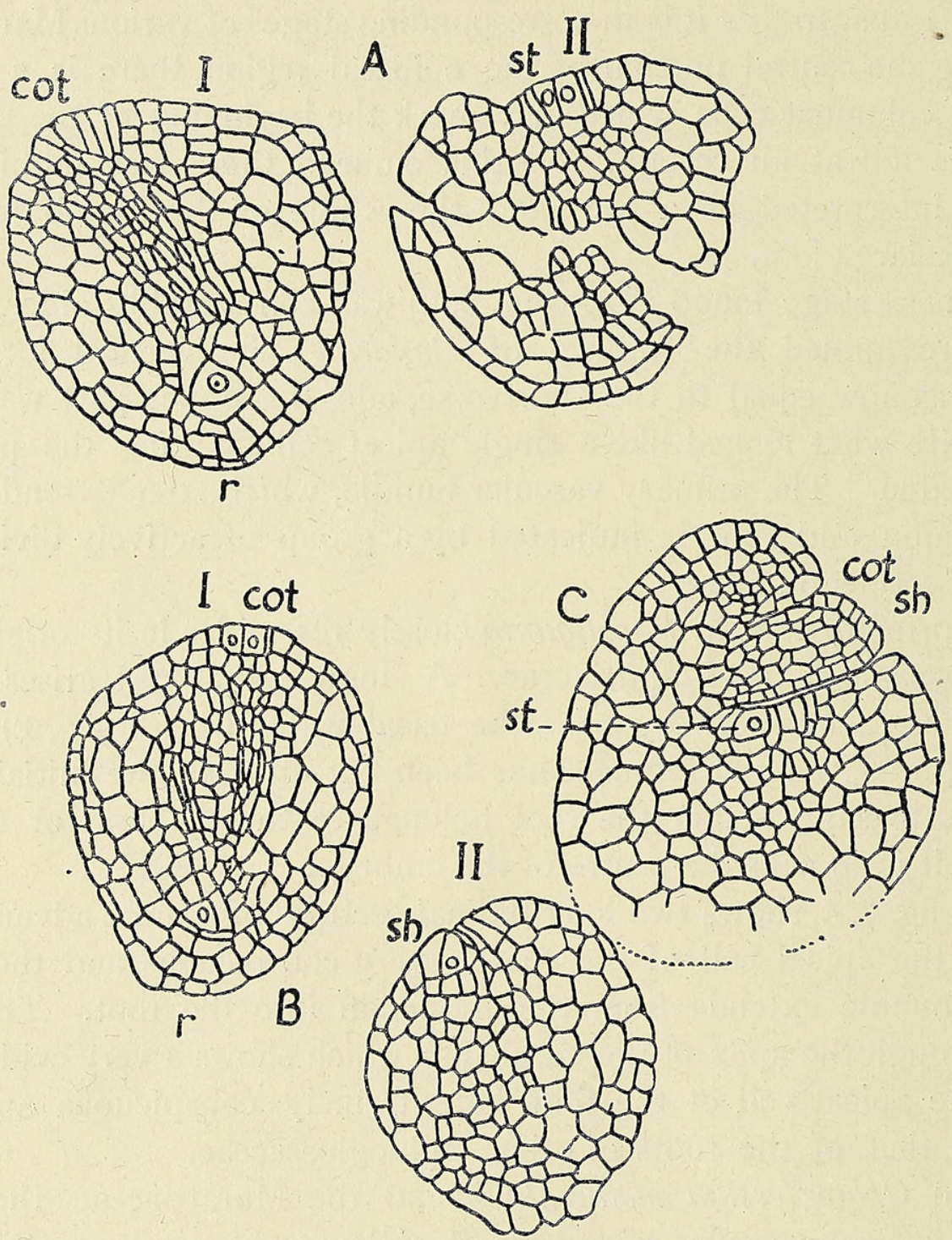

TEXT-FIG. 7. A. Two longitudinal sections of an embryo, cut in the plane of the cotyledon, cot. The root, $r$, is very conspicuous. st., stem apex. $\times 100$. B. Two sections of a similar embryo, cut in a plane at right angles to that of A. I shows the leaf-traces of the cotyledon and second leaf. C. Somewhat oblique section of an older embryo showing the conspicuous sheath, sh., at the base of the cotyledon.

vascular bundle belonging to the second leaf is formed very early and joins the primary bundle extending through the cotyledon and root. The stem apex occupies the space between these bundles, but has no procambium tissue developed from it. The relation of the vascular bundles to the leaves and stem apex is best seen in a series of cross-sections (see Textfig. 10). 
The cotyledon is provided with a very conspicuous basal sheath, which is not found in B. virginianum. At an early period there is active growth at the base of the cotyledon, which soon extends over the stem apex and second leaf, which lie in a narrow cleft formed by this overarching basal sheath of the cotyledon (Text-fig. 7, C). For some time the sheath is the most conspicuous part of the cotyledon, the apical portion of the leaf being relatively insignificant.

\section{THE RoOT.}

The characteristic tetrahedral apical cell of the root becomes established at an early period, and soon shows a regular segmentation. The root grows rapidly and emerges on the ventral surface of the gametophyte (Fig. 4). It is much the most conspicuous feature of the young sporophyte and reaches considerable size before the emergence of the cotyledon.

The root grows vertically downward through the tissues of the footor perhaps it would be more accurate to say it becomes incorporated with it, as the foot as such becomes quite unrecognizable, its tissues merging insensibly with those of the root, and its lower portion forms practically part of the root-cap, and it is ultimately destroyed as the root-cap is renewed from the segments of the apical cell. The axis of the root coincides with that of the cotyledon, so that almost from the first the bipolar character of the young sporophyte is established.

Some time after the root has broken through the ventral surface of the gametophyte, the cotyledon elongates and ruptures the dorsal surface, so that the position of the young sporophyte is very much like that of the Marattiaceae, or Ophioglossum moluccanum (Fig. 6; Text-fig. 1).

The apex of the cotyledon becomes differentiated into petiole and lamina, the latter being bent over, much as in B. virginianum. The young cotyledon shows a definite apical cell which appears narrowly triangular in longitudinal section.

The massive basal sheath extends over the stem apex, which, together with the second and third leaves, is completely enclosed within the sheath (Text-figs. 8, 9). A single strand of procambium extends through the petiole, but no vascular tissue develops in this sheath. The bundle in the petiole is continued downward into the root without a break, and it is quite impossible to determine the limits between leaf and root.

The second leaf develops in much the same way as the cotyledon, and its basal sheath envelops the stem apex and next younger leaf in exactly the same fashion. The details of the apical growth were not followed, but probably would not differ materially from the cotyledon.

The leaf-trace of the second leaf begins to form almost as soon as the leaf can be recognized, the same being true of the third leaf. The bundle 
of the second leaf joins the primary strand of the cotyledon and root at a considerable distance below the level of the stem apex.

The first tracheary tissue in the primary bundle is formed at a point a little above the point of junction with the trace from the second leaf. The primary tracheary tissue consists of a bundle of short reticulate tracheides.

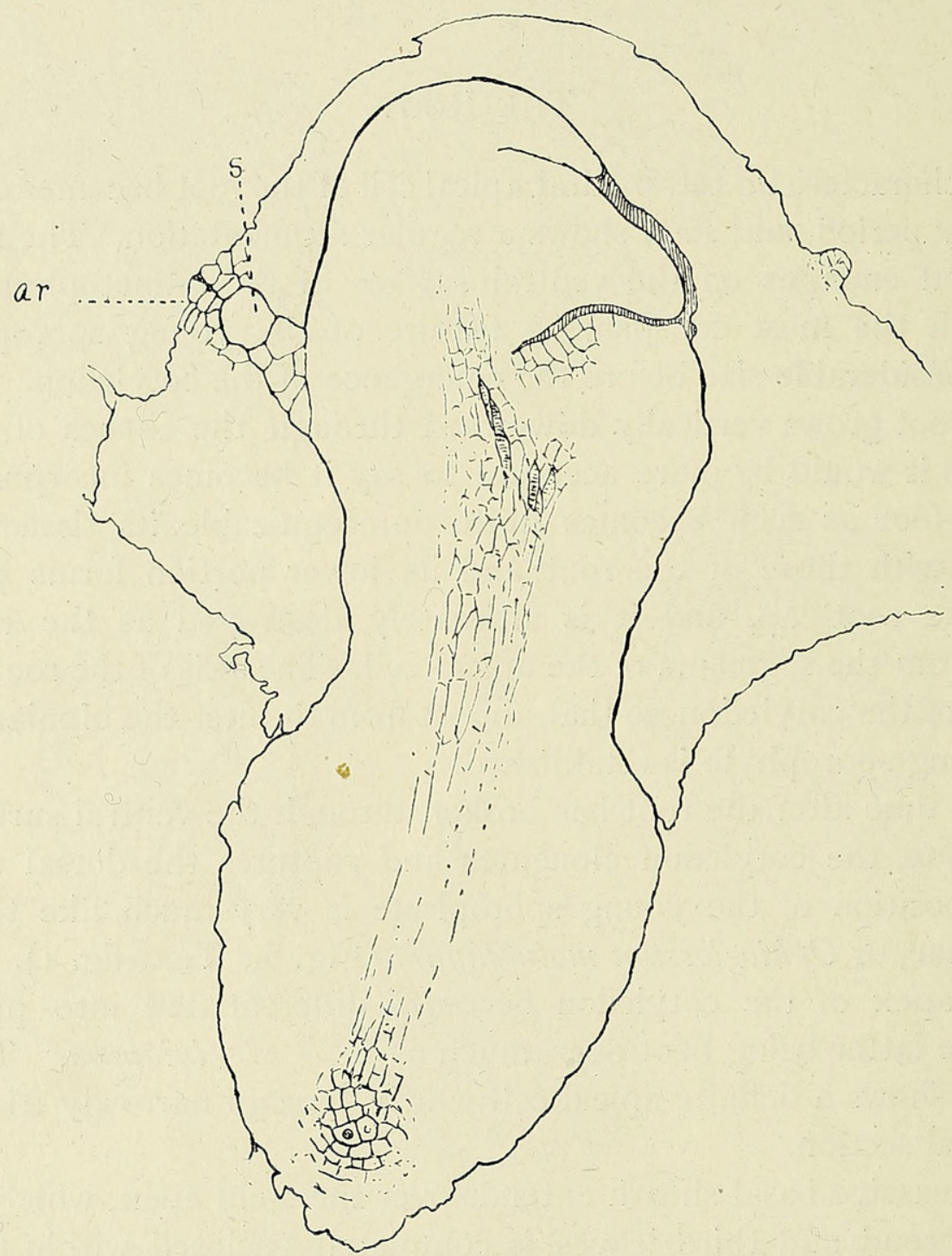

TEXT-FIG. 8. From a microphotograph of a young sporophyte just before the emergence of the cotyledon. s., suspensor; ar., archegonium. Photograph by Dr. H. L. Lyon.

From this point the development of permanent tissue in the bundle proceeds upward into the petiole and downward into the root. Shortly after the formation of the first tracheary tissue in the primary bundle, tracheides appear at the base of the trace from the second leaf, where it joins the primary bundle, and from this point the formation extends upward.

With the elongation of the cotyledon it soon breaks through the overlying tissues of the gametophyte and emerges upon its dorsal side. Then, 
pushing through the soil, it appears above ground as a small ternate leaf, with a long slender petiole (Fig. 7).

The venation of the leaf-lobes is dichotomous, and suggests that the ternate form of the lamina is due to an unequal dichotomy such as can often be seen in many ferns in the early leaves intermediate between the
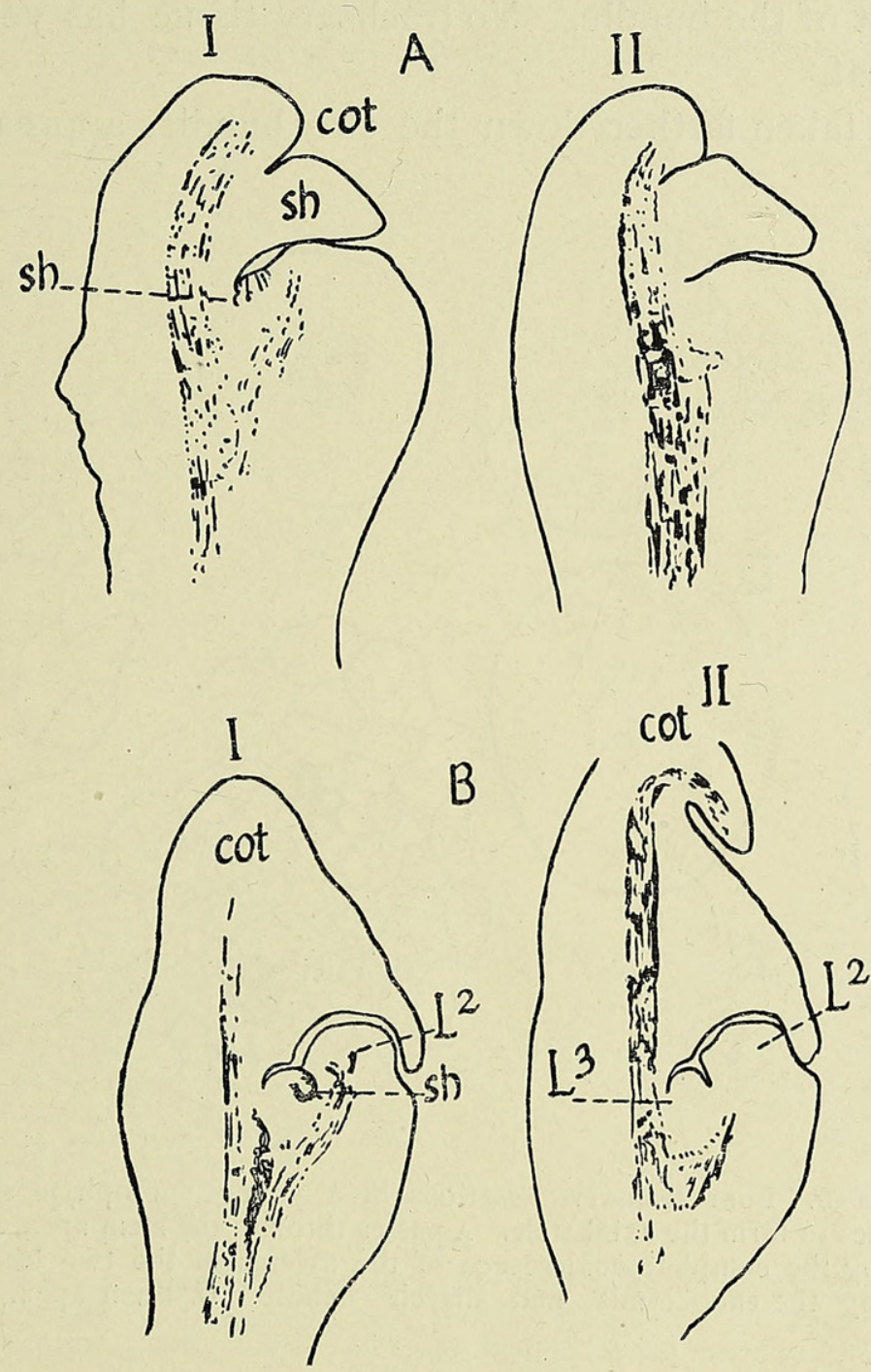

TEXT-FIG. 9. A. Two longitudinal sections of a young sporophyte, showing the arrangement of the vascular bundles. $x$ about 70. B. Two sections of a somewhat older sporophyte, showing second and third leaves, $\mathrm{L}^{2}, \mathrm{~L}^{3}$.

dichotomously lobed cotyledon and the pinnate leaves of the older sporophyte.

The position of the young sporophyte, with reference to the gametophyte, is exactly the same as in the Marattiaceae, the bipolar sporophyte completely perforating the gametophyte, the cotyledon emerging above, the root below. It must be remembered, however, that in the Marattiaceae, as in the ordinary ferns, the archegonia are upon the ventral surface of the prothallium instead of upon the dorsal side, as is the case in Botrychium. 
The arrangement of the vascular bundles can best be understood from a series of cross-sections. Text-fig. IO, A-F, shows several sections from such a series from a young sporophyte of about the same age as that shown in Text-fig. 8; A shows the section passing through the stem apex, $x$, which with the second leaf is surrounded by the sheathing base of the cotyledon. The vascular bundle of the latter shows the first tracheides, at the inner limit of the bundle. No tracheary tissue has yet been formed in the second leaf.

In sections taken farther down the two bundles approach, and finally
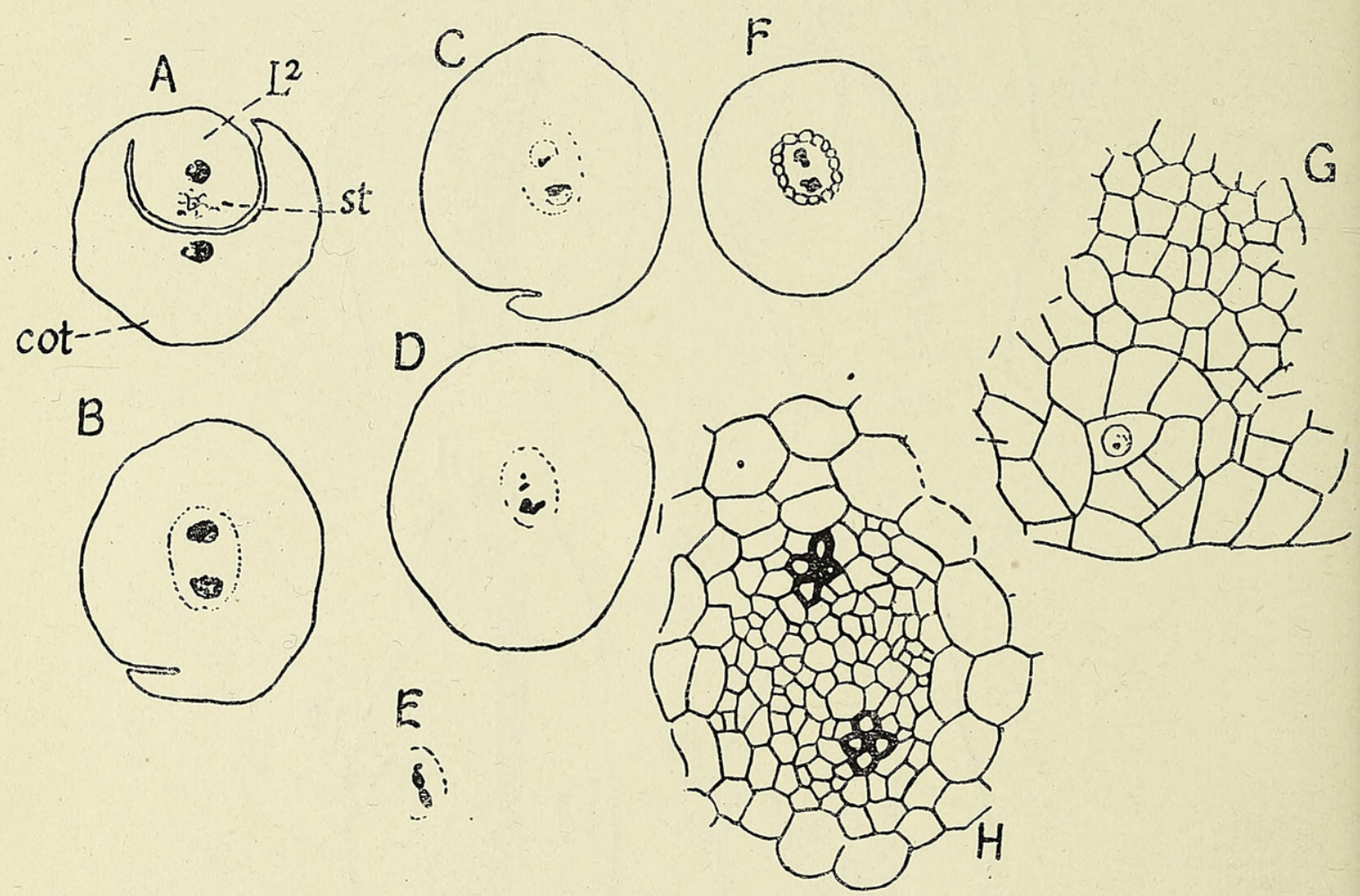

TeXT-FIg. IO. A-D. Four transverse sections of a young sporophyte showing the coalescence of the leaf-traces to form the axial stele. A passes through the stem apex, st. $\mathrm{L}^{2}$ youngest leaf. E. The stele, showing the complete coalescence of the xylems of the two leaf-traces. F. Section of the root, showing the endodermis and diarch bundle. G. Stem apex. $\times 270$. H. Rootbundle. $\times 2$ \%

coalesce. While the two bundles maintain their identity for some time, they occupy a pretty well defined oval area, which, however, is not limited by a recognizable endodermis. After the coalescence of the bundles is completed, and the stele enters the root region, a definite endodermis of the typical form is easily seen ( $\mathrm{F}, \mathrm{H})$.

Just before the two leaf-traces coalesce, the first tracheary tissue can be seen in the trace from the second leaf, and the xylems of the two leaftraces form a continuous band at the junction of the two bundles (E). The two leaf-traces are now completely merged into a common 'stele', which is continued downward into the root. It is quite impossible to say where the foliar portion of the stele ends and that of the root begins. 
The suspensor increases in size and becomes multicellular; but it is not quite clear whether this is entirely the result of division in the primary suspensor cell or whether the cells of the embryo adjacent to the original suspensor contribute to it.

The development of the sporophyte was not followed beyond the time of the emergence of the cotyledon and primary root. At the time the lamina of the cotyledon expands only one root, as a rule, could be seen. Some cases were observed (Fig. 5) where a short lateral root had developed
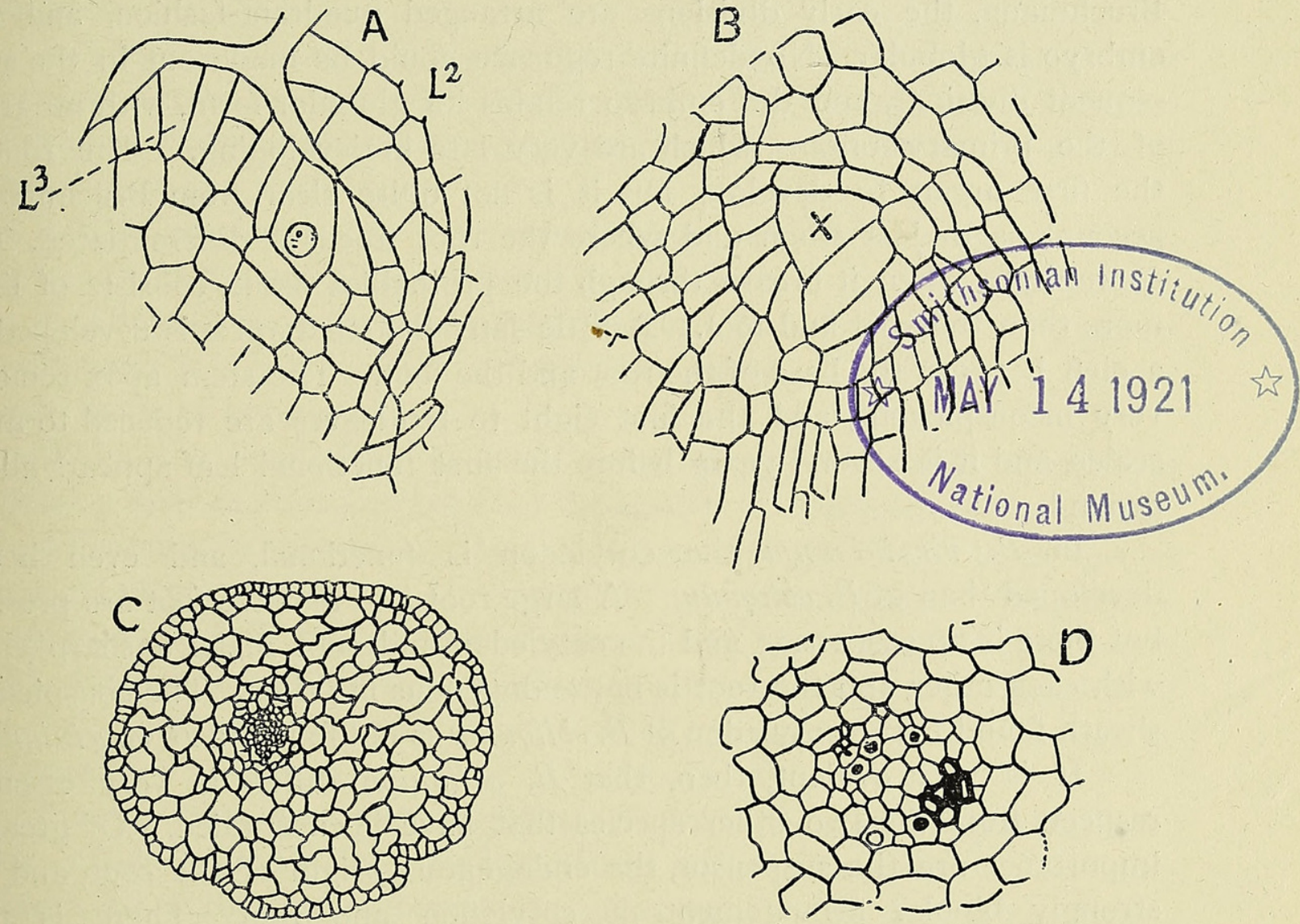

TEXT-FIG. II. A. Longitudinal section of the stem apex of a young sporophyte. $\times 2$ \%o. The large nucleated cell is the apical cell of the stem; $L^{2}, L^{3}$, second and third leaves. B. Root apex. $\times$, apical cell. $\times 270$. C. Cross-section of the petiole of the cotyledon. $\times 70$. D. Monarch bundle of primary root. $\times 270$.

from the primary one, but this was probably the result of some injury to the apex of the primary root. The bundle of the first root is usually diarch, as in B. Lunaria and B. virginianum, and the endodermis is very conspicuous (Text-fig. IO, H). Not infrequently, however, one xylem is suppressed and the bundle is monarch, as in Ophioglossum vulgatum (Text-fig. I I, D).

While it is common for more than one archegonium to be fertilized, and several one-celled embryos are frequently found on a gametophyte, in only two cases were two older embryos encountered, and one of these was much better developed than the other, indicating that the smaller one would 
finally succumb. Bruchmann found two complete sporophytes attached to the same gametophyte in B. lunaria, but the writer found no such cases in the specimens of $B$. obliquum that were examined.

There is no question that the vascular system in the young sporophyte of $B$. obliqunm is composed exclusively of leaf- and root-traces. No cauline stele is present, and in this it agrees with Ophioglossum moluccanum and the Marattiaceae, especially Danaea. ${ }^{1}$

The embryos of $B$. Lunaria and $B$. virginianum differ greatly from each other and also from $B$. obliquum. In the former, according to Bruchmann, the early divisions are arranged quadrant-fashion, and the embryo is globular. No definite sequence could be made out in the subsequent divisions, and the embryo retains its globular form, with no trace of the primary organs, which are very late in developing. The root is the first organ to develop, but it is not quite clear from Bruchmann's account as to just when and where the root apex is differentiated. The sporophyte, when it breaks through the prothallial tissue, consists of little more than the root and foot. A little later the stem apex is developed in a cleft between the base of the root and the foot. The stem apex remains very inconspicuous, and the first eight to ten leaves are reduced to mere scales, and it is several years before the first functional leaf appears above ground.

In $B$. virginianum the cotyledon is functional, and even better developed than in B. obliquum. A large root and massive foot are present, but there is no suspensor, and the cotyledon and root make a sharp angle with each other, and the root is not endogenous in origin. The conspicuous sheath found in the cotyledon of B. obliqum is not found in B. virginianum.

It is very evident, then, that $B$. obliqum differs in very essential respects from the two other species that have bcen studied. Of greatest importance are the suspensor, the endogenous origin of the root, and the strongly bipolar arrangement of cotyledon and root. There is thus a marked resemblance on the one hand to Ophioglossum moluccanum, and on the other to the Marattiaceae. The presence of a suspensor is shared with Helminthostachys, ${ }^{2}$ which on the whole among the Ophioglossaceae seems to be most nearly related to the Marattiaceae. Of the latter Danaea closely resembles $B$. obliquum, both in the presence of a suspensor, and in the general structure of the young sporophyte. The genus Macroglossum also possesses a conspicuous suspensor.

\section{Summary and Conclusion.}

I. The gametophyte and sexual organs of Botrychium obliqumm do not differ essentially from those of the other species of Botrychium.

${ }^{1}$ Mr. Baas-Becking, who is now studying the development of the young sporophyte, has found that the second root originates exactly as in Danaea.

2 Lang : loc. cit. 
2. The embryo differs in several important particulars from both B. Lunaria and $B$. virginianum. It resembles the latter in having the cotyledon well developed, but differs in the endogenous origin of the root, in the bipolar arrangement of cotyledon and root, and especially in the presence of a suspensor. The embryo is much more like that of some species of Ophioglossum and Danaea than it is like other species of Botrychium.

3. The stem apex grows from a single apical cell, which is much like that of Ophioglossum vulgatum. The young cotyledon also has a single apical cell.

4. There is a single primary vascular strand which extends without interruption from the cotyledon into the root. There is no cauline stele, and the primary vascular strand is augmented later by additions from the traces of the second and third leaves.

5. The cotyledon has a ternate lamina with dichotomous venation. The bundle of the petiole is collateral in structure.

6. The root early develops a conspicuous tetrahedral apical cell, and its development is much like that of the later roots. The bundle is usually diarch, but may be monarch.

While the similarities in both gametophyte and adult sporophyte indicate a near relationship between the species of Botrychium, the remarkable differences in the embryo and young sporophyte of the three species investigated may warrant a division of the genus into three. B. Lunaria, $B$. obliquum, and $B$. virginiamum represent three types of adult sporophyte which differ in a number of particulars, viz. form, texture, and venation of the leaf; size of sporangium; position of sporangiophore; character of leaf-base.

Prantl ${ }^{1}$ recognizes two subgenera, Eubotrychium and Phyllotrichium, while Milde ${ }^{2}$ divides into Eubotrychium and Osmundopteris. The first includes all of the species except $B$. virginianum and B. matricariaefolium. Most of the species of Eubotrychium belong to the 'Ternatum' group, of which B. obliquum is an example. These have a fleshy, ternately compound, sterile leaf-segment, while the stalk of the sporangiophore is inserted close to the base of the petiole.

Should further investigation show that the other species of the Ternatum group agree with $B$.obliquum in the structure of the embryo, there would be ample reason for accepting Lyon's genus Sceptridium.

The writer believes that $B$. virginianum differs sufficiently from the other species to warrant raising Osmundopteris to generic rank, and restricting the name Botrychium to B. Lunaria and its near allies.

1 Ber. d. deutsch. bot. Ges., i. 349 .

2 See Underwood: Our Native Ferns, p. I 32, I 888. 
${ }_{15} 8$ Campbell.- The Gametophyte, Esc., of Botrychium obliquum.

\section{EXPLANATION OF PLATE VIII.}

Illustrating Mr. D. H. Campbell's paper on the Gametophyte and Embryo of Botrychium obliquum.

Figs. I, 2. Young gametophytes seen from above. $\times 20$.

Fig. 3. An older gametophyte, seen from above, showing the median antheridial ridge.

Fig. 4. Adult gametophyte, with the root of the young sporophyte emerging on the ventral side. $\times 40$.

Fig. 5. Gametophyte with young sporophyte attached. The cotyledon emerges from the dorsal surface, the root, $v$, from the ventral side. A lateral root has formed from the primary root. $\times 5$.

Fig. 6. Gametophyte, with young sporophyte attached. $\times 3$.

Fig. 7. Young sporophyte, showing the ternate cotyledon. $\times 3$.

Fig. 8. Median longitudinal section of young gametophyte, showing the growing-point, $x$. $\times 5^{8}$. The shaded portion indicates the region occupied by the mycorrhiza.

Fig. 9. Apical region of the gametophyte. $\times 360$.

Fig. Io. Two cells from the gametophyte showing the endophytic fungus. $\times 600$. N, nucleus of the gametophytic cell ; $s p$. ., 'spore' of the fungus.

Fig. II. Transverse section through the antheridial ridge of a young gametophyte. $\times 95$. \&, young antheridia; , an archegonium.

Fig. I 2. Transverse section of an older gametophyte. $\times 5^{8}$. The shaded area indicates the extent of the region occupied by the endophyte.

Figs. I3, I 4. Young antheridia seen in median longitudinal section. $\times 480$.

Fig. I5. An older stage. $\times 360$. 0 , opercular cell.

Fig. 16. Surface view of an antheridium, showing the opercular cell, $o . \times 360$.

Fig. I 7. Spermatocytes with nearly ripe spermatozoids. $\times$ II 20.

Fig. I8. Two free spermatozoids. $\times$ II 20.

Figs. 19, 20. Very young archegonia. $\times 480$.

Fig. 21. Archegonium, showing primary neck canal cell. $\times 360$.

Fig. 22. Venter of a ripe archegonium. The ventral canal cell, $v$, not separated by a wall from the egg-cell. Two nuclei in the neck canal cell. 



11 .
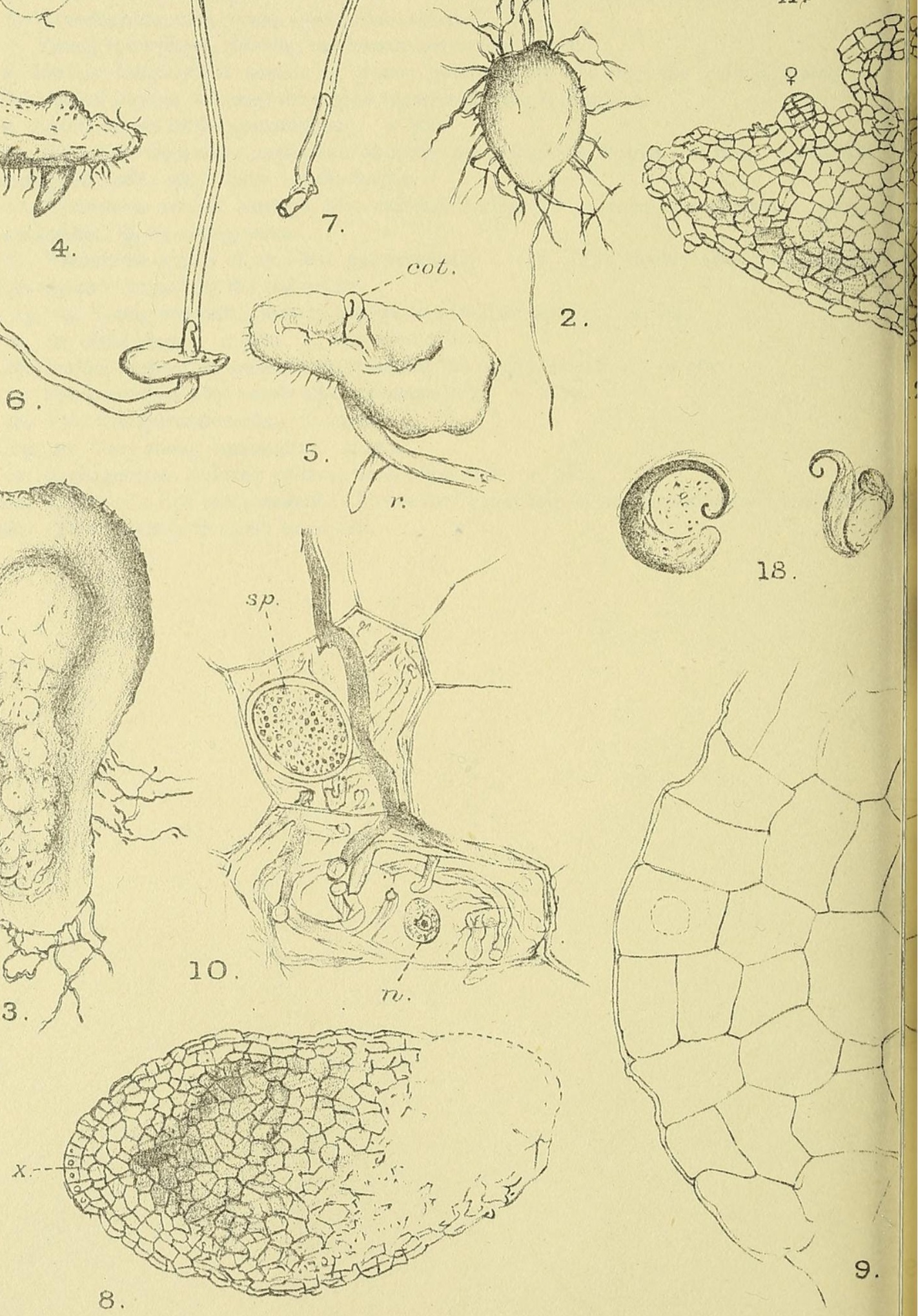

D.H. Campbell del

CAMPBELL - BOTAYCHIUM. 
Vol. YXXV PL.VIIII.
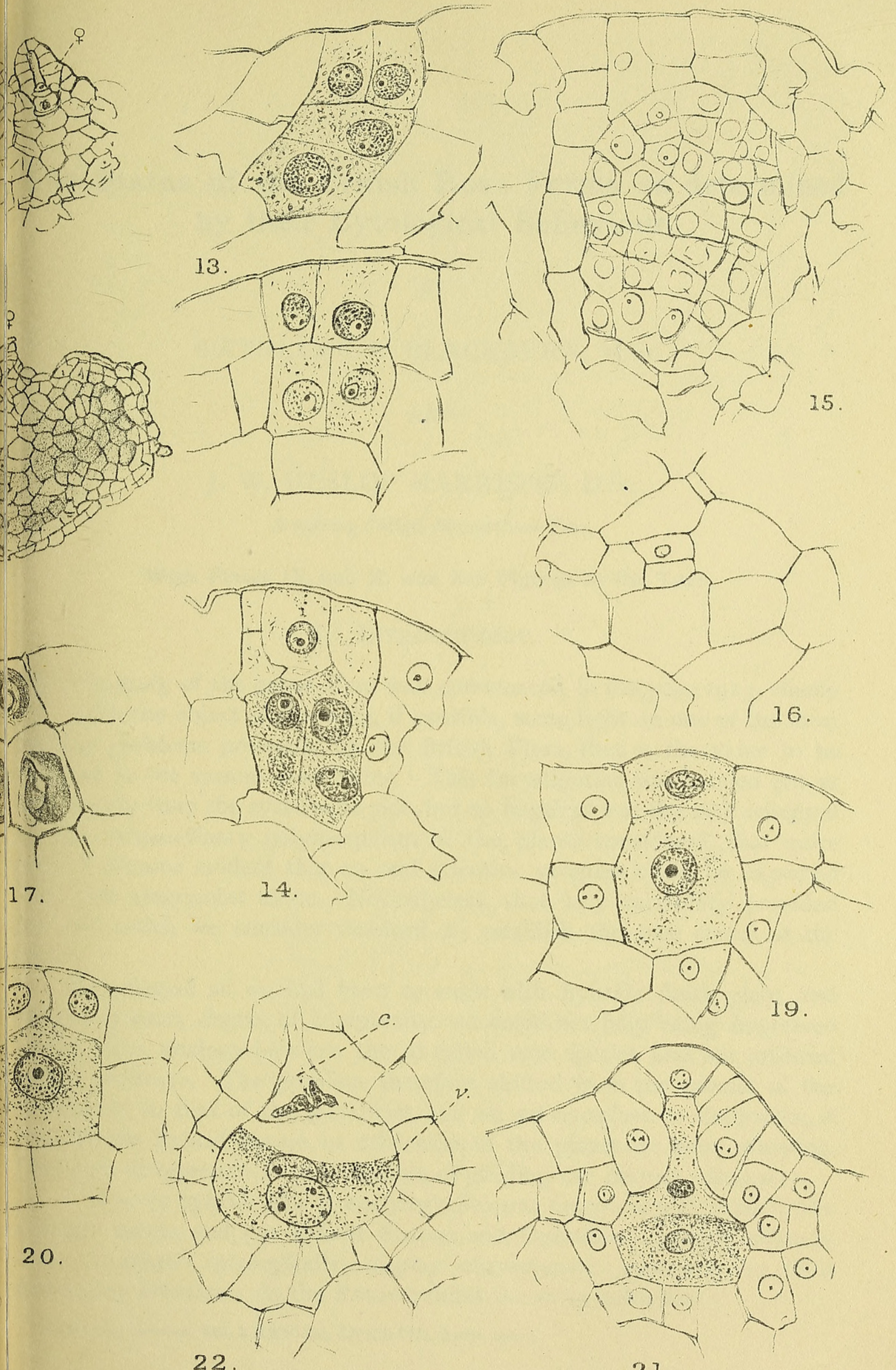


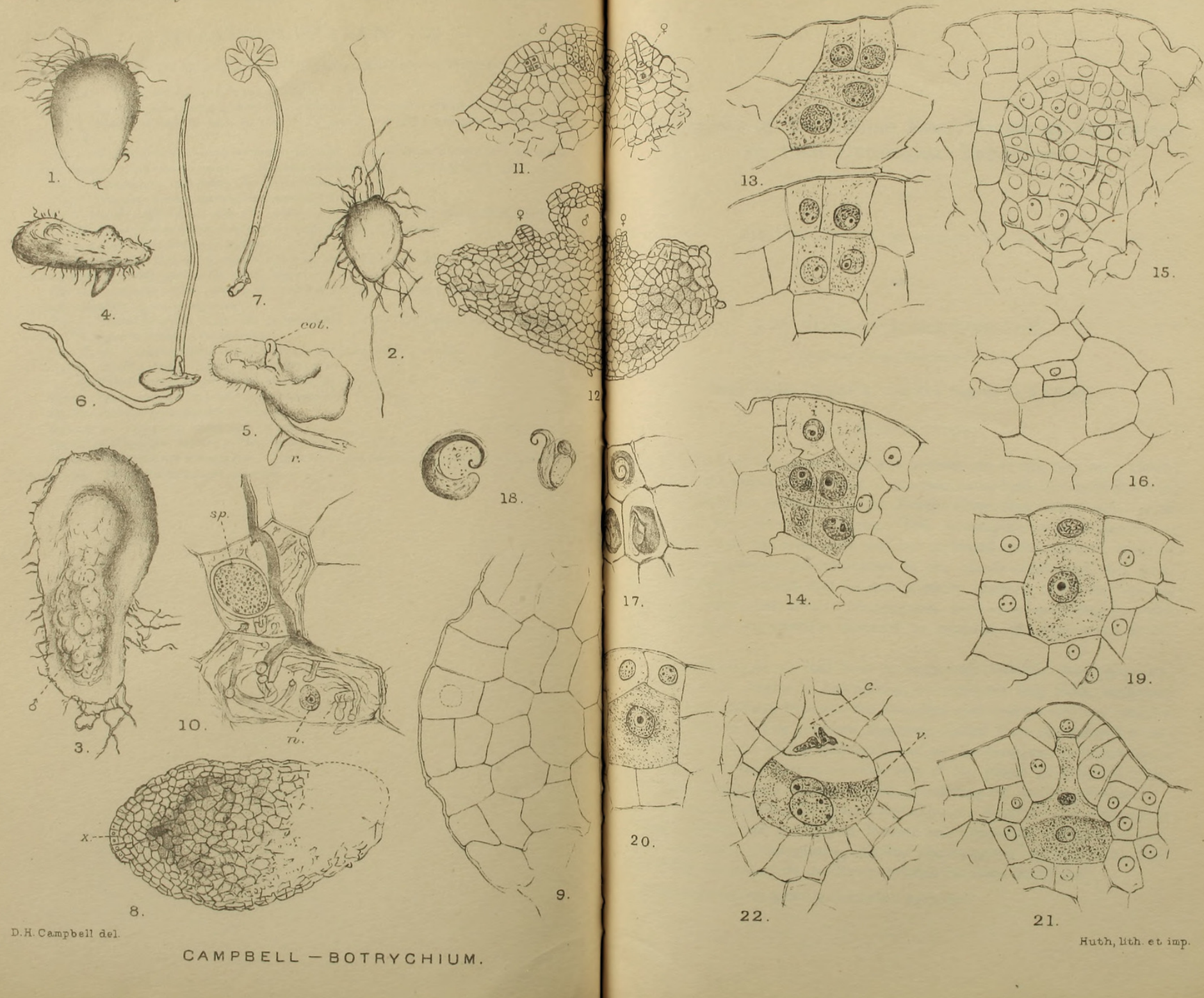




\section{$2 \mathrm{BHL}$ Biodiversity Heritage Library}

Campbell, Douglas Houghton. 1921. "The gametophyte and embryo of Botrychium obliquum, Mühl." Annals of botany 35, 141-158.

https://doi.org/10.1093/oxfordjournals.aob.a089752.

View This Item Online: https://www.biodiversitylibrary.org/item/235780

DOI: https://doi.org/10.1093/oxfordjournals.aob.a089752

Permalink: https://www.biodiversitylibrary.org/partpdf/318997.

\section{Holding Institution}

Smithsonian Libraries

\section{Sponsored by}

Biodiversity Heritage Library

\section{Copyright \& Reuse}

Copyright Status: Not in copyright. The BHL knows of no copyright restrictions on this item.

This document was created from content at the Biodiversity Heritage Library, the world's largest open access digital library for biodiversity literature and archives. Visit BHL at https://www.biodiversitylibrary.org. 